\title{
Effects of oil spillage on Soil and Surface Water in Odoro Ikot Ukanafun Area Akwa Ibom State
}

\author{
${ }^{* 1}$ IDO, U. S.; EGESI, N.
}

Department of Geology, University of Port Harcourt, Nigeria.

Keywords: Tozicity, heavy metals, soil and water, WHO standard, Odoro Ikot Ukanafun, Akwa Ibom State Nigeria.

\begin{abstract}
A hydrogeochemical survey of water and soil sample in Odoro Ikot and its environment was carried out using Atomic Absorption Spectrometry (AAS) techniques. It was done to assess the impact of oil spillage on soil and surface water in the area. The soil samples were taken from the top to a depth of $30 \mathrm{~cm}$ at the interval depth of $5 \mathrm{~cm}$ each. Results obtained from these analyses were compared with World Health Organization (WHO) Department of Petroleum Resources (DPR)and Federal Environmental Protection Agency (FEPA) standards. The following parameters were measured and analyzed, temperature, $\mathrm{pH}$, electrical conductivity, oil/grease, copper $(\mathrm{Cu})$, cadmium $(\mathrm{Cd})$ lead $(\mathrm{Pb})$, Zinc $(\mathrm{Zn})$, chromium $(\mathrm{Cr})$, Iron $(\mathrm{Fe})$, phosphorus, (Pox) and sulphate $\left(\mathrm{SO}_{4}\right)$. The results of the analysis show that the surface water samples exceeds the WHO, FEPA and DPR acceptable standards. Apart from the water $\mathrm{pH}$ which was almost moderately acidic and oil/grease value in the study area, other parameters also exceeds the recommended standards, therefore there is need for remediation or clean up exercise to be carried out in the study area. The comparison with the soil sample analytical results show that the crude oil has polluted the soil and rendered it unsuitable for agricultural purpose since the ecology has been damaged and the soil degraded. @JASEM
\end{abstract}

DOI: http://dx.doi.org/10.4314/jasem.v17i2.3

The effect of pollution studies on surface water and soil are mostly associated with an impact from the industrial operation or any other source of pollution. It mainly seeks to define the effect of damage and the measures, which could be adopted to control the impact or rehabilitate the ecosystem. According to a Untied Nations body, the Group of Experts on Scientific Aspects of Marine Pollution (GESAMP 1990), pollution is the introduction by man directly or indirectly of substance or energy into the environment resulting in such deleterious effects as harm to living organism, impairment of marine activities, reduction of amenities and harm to plants and crops.

In this research, attempt will be made to look at the impact of oil pipeline blow out on surface water and soil in Odoro Ikot, the action of the oil spill degrade and pose some environmental threats such as pollution of surface water and underground water and soil. The factors that can contribute to oil spillage are as follows:
Natural causes (eg rain, flood), Corrosion (accidental contamination); Faulty facility; Sabotage Pipeline leakage; Human error (operational and maintenance error).

Effects pertaining to these problems are much on the ecosystem. Therefore, farmlands, surface water, soil, air, marine/aquatic lives are damaged and degraded. According to the report obtained from the villagers, the oil spillage was by natural causes, an estimated 2,000 barrels of crude oil was reported spilled into adjourning, farmland and water body within the Odoro Ikot, community. The spill point was located at the valley near Odoro Ikot water front, large quantity of spilled crude drained into the river and was carried down the river course that leads to Ogoni. According to the report acquired from the villagers, crude oil spill on a valley in Odoro Ikot near the waterfront and spread from the valley down to the river and impacted about 50

hectares of farmland mainly along the rivers and its tributaries. The oil affected the rivers down stream and upstream on the spill flow

*Correspondence authors Email:ubaegesi@yahoo.co.uk 


\section{Effects of oil spillage on Soil 188}

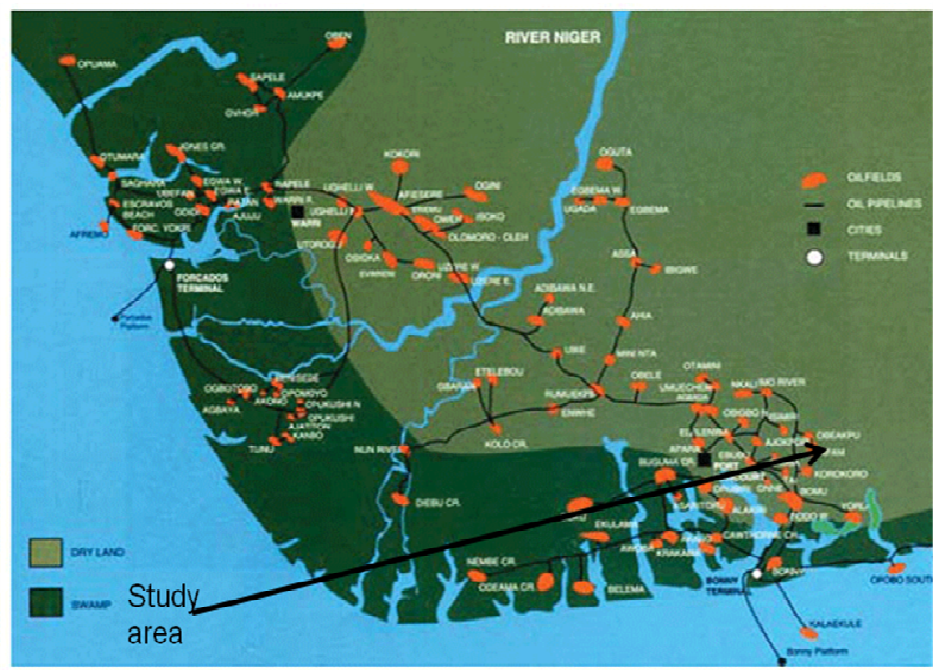

Fig.1 Oil producing sites in the Niger Delta region of Nigeria

Source: Supply chain management practice in SPDC 2005

Pathway. They said the cleaning exercise was done by Shell Petroleum Development Company (SPDC) when they came in to drill and the well has been plugged till date. After the oil spill in Odoro Ikot community, the effects of the pollution on surface water and soil have not been re-investigated according to the villagers. Due to this fact, the research was carried in order to evaluated concentration of pollutants/contaminants caused by the oil spillage in water and soil samples at present. The problems likely to be encountered here, are degradation of the soil and unsuitability of the surface water for drinking and domestic uses due to pollution.

Regional Geology Of The Area: The Area is located between Latitude $4^{0} 4^{\prime}-4^{0} 50^{\prime} \mathrm{N}$ and Longitude $7^{0} 35^{\prime}$ - $7^{0} 4^{\prime}$ E accessible from Ukanafun Local Government headquarter to Odoro Ikot communities in Ukanafun Local Government Area, Akwa Ibom State. Odoro Ikot is well drained by small fresh water stream which flow into the major river that led to Ogoni. The region is situated on a flat land. The streams however covey a lot of eroded materials in the form, of sands and gravels into the river the economic resources of the area include farming and fishing.

Odoro Ikot is found in the Niger Delta Basin and is the same with the geology of Niger Delta. The main Formations are recognized in the subsurface of stratigraphic unit in modern Niger Delta by Frank and Cordry (1967). The three Formations were laid down under marine continental and transitional environmental respectively.

In a continental fluviatile environment, the Benin Formation was deposited and consists mainly of sands, gravels and back swamps deposits that vary in thickness from 0-4000ft.The Agbada Formation comprises the inter-bedded sandstones and shales. The Formation was laid in a brackish to marine fluviatile, parallie and fluvio-marine environment. The Agbada Formation varies in thickness from 4000-8000ft and becomes shaler with depths. The Akata Formation varies in thickness from $>9000 \mathrm{fts}$ and is deeper. It consists with occasional silt, forming lenses and turbiditer sands. Formation ages in increasing order are as follow,

Benin Formation Miocene, Agbada Formation Eocene and Akata Formation Paleocene Frank and Cordry (1967).

Hydro-Geology Of The Area: Odoro Ikot has the hydrogeological conditions similar to the Niger Delta. The Benin Formation is the uppermost Formation in the sedimentary sequence of Niger Delta complex. The Formation is generally water bearing (most aquifers are located in the region)

The depths to water table which decrease seaward very from about $10 \mathrm{~m}$ (in land) to less than $0.5 \mathrm{~m}$ at the coast (Akpokodje, 2001). It is the main sources of portable ground water in the Niger Delta area. Hence, a multi aquifer system is developed due to interactions of sands and shale Egboka (1988) 
described the area as belonging to the Niger Delta Basin hydrogeogical province.

\section{MATERIALS AND METHODS}

Field And Laboratory: The $\mathrm{pH}$ of the sample was determined using a glass-electrode $\mathrm{pH}$ meter. Prior to $\mathrm{pH}$ measurements, the meter was calibrated with $\mathrm{pH}$ 4.0 and $\mathrm{pH} 9.0$ the $\mathrm{pH}$ meter was stabilized and the fresh water samples was kept at some temperature as the buffered solution used $20 \mathrm{ml}$ of water sample was poured into a clean $50 \mathrm{ml}$ beaker, this glass electrode immersed and the reading of the meter recorded, this was done in duplicate to reduce error.

The temperature of the sample determine at the sample collection site by immersing the bulb of the thermometer into flowing rivers and then reading of the stem. Duplicate readings were recorded in $0^{0} \mathrm{C}$. Sample preparation for the determination of the heavy metals $5 \mathrm{~kg}$ of each of the samples was cut into small pieces dried at $105^{\circ} \mathrm{C}$ and were pounded in a mortar until a powder was produced which was stored in dry plastic bottles. $1.00 \mathrm{~g}$ oven dried powdered samples was weighed into a $100 \mathrm{~cm}^{3}$ Kjeldhal digestion flask, $5 \mathrm{~cm}^{3}$ of $\mathrm{cm}$ contracted nitric acid $\left(\mathrm{NO}_{3}\right)$ was added followed by $1 \mathrm{~cm}^{3}$ each of concentrated sulphuric acid $\left(\mathrm{H}_{2} \mathrm{SO}_{4}\right)$ and $60-62 \%$ perchloric acid $\left(\mathrm{HClO}_{4}\right)$.

The flask was placed in a slanting position on an electric heating mantle in a fume cupboard and heat was supplied gradually until the evolution of white dense fumes of $\mathrm{H}_{2} \mathrm{~S}_{4}$. The volume of the digest was reduced by heating but not to dryness. The flask was set aside to cool after which the content was diluted with distilled demonized water and then filtered into a $50 \mathrm{~cm}^{3}$ volumetric flask. The content was made up to the mark with distilled water and used for the determination of the heavy metals of interest with Atomic Absorption Spectrophotometer (AAS) Buck scientific model 240. The sample solution as well as standards were pirated into the AAS at $217.0 \mathrm{~nm}$, 253.70nm, 288.80nm, 327.40nm, 232.0nm, 213.90nm, 357.90nm for $\mathrm{Pb}, \mathrm{Hg}, \mathrm{Cl}, \mathrm{Cu}, \mathrm{Nc}, \mathrm{Zn}$, and $\mathrm{Cr}$ respectively.

Calibration curves were prepared from the readings of the standards while sample readings were extrapolated from the standard curves. Calculation/converting of $\mathrm{mg} / \mathrm{l}$ to $\mathrm{mg} / \mathrm{kg}$ of the weigh of the sample used in the project in $5 \mathrm{~g}$

There to convert $\mathrm{mg} / \mathrm{L}$ to $\mathrm{mg} / \mathrm{kg}$
Metal $=\frac{\text { cppm }}{10^{4}} \times \frac{\text { solution volume }\left(\mathrm{cm}^{3}\right)}{\text { sample weignt }(\mathrm{g})}$

\section{RESULTS AND DISCUSSION}

Results of the chemical analysis carried out are presented in tables 1 and 2 compare with tables 3, 4 and 5. Fig 2. shows a comparison of soil sample with FEPA (1999). Fig 3. Shows comparison of surface water sample with the FEPA guideline standard in drinking water. Fig.4 with WHO (1993). Fig 5, 6, and 7 , respectively with DPR standard. The electrical conductivity for surface water varies from 121.5 $\mu \mathrm{s} / \mathrm{cm}$ to $17.6 \mu \mathrm{s} / \mathrm{cm}$ which meets the highest desirable limit of the water in Odoro Ikot is suitable for domestic purpose which the FEPA standards for electrical conductivity in surface water has not been determined.

The electrical conductivity of soil ranges from 968$986 \mu \mathrm{s} / \mathrm{cm}$ which exceed the $4 \mu \mathrm{s} / \mathrm{cm}$ FEPA standards for soil quality. The $\mathrm{pH}$ levels shows almost moderately acidic on surface water of this area. The acidic nature may be caused by free carbondioxide further atmospheric getting into this surface water and soil. The soil $\mathrm{pH}$ in varies from 5.21-5.40 which does not meet the FEPA standards, it is acidic.

Chemical Parameters For Water Sample: The pH values obtained from the analysis of the study area ranges 5.21-5.40 which does not meets the WHO (1993) and FEPA (1999) 6.5-8.5 standards for drinking water, this maker the water in Odoro Ikot not suitable for domestic activities.

Oil/Grease: The mineral oil value of Odoro Ikot water is $65.28 \mathrm{mg} / \mathrm{l}$. This result however exceed the WHO (1993) and FEPA (1999) standard which make the water not suitable to domestic purposes. WHO standard $(0.01-0.5 \mathrm{mg} / \mathrm{L})$ while FEPA standard is $0.05 \mathrm{mg} / \mathrm{L}$.

Copper $(\mathbf{C u})$ : The average range of copper from the water analysis performed in Odoro Ikot is $5.88 \mathrm{mg} /$ this result exceed the WHO (1993) and FEPA (1999) standards which falls between 0.05$1.5 \mathrm{mg} / 1$. This makes the water in the study area not suitable for domestic purposes.

Cadmium (Cd): The average range of cadmium from the water analysis carried out in Odoro Ikot is $2.88 \mathrm{mg} / \mathrm{l}$. This results exceed the WHO (1993) and FEPA (1999) guideline and standard is $0.05 \mathrm{mg} / \mathrm{l}$. Thus the water is not suitable for drinking and other domestic purposes. 
Lead $(\mathbf{P b})$ : The average range of lead in the study area is $10.14 \mathrm{mg} / \mathrm{l}$. This result exceed WHO (1993) and FEPA (1999) standards for drinking water, which is $0.05 \mathrm{mg} / \mathrm{l}$. The water is not suitable for domestic purposes.

Zinc (Zn); The average range of zinc from the water analysis carried out in Odoro Ikot is $3.45 \mathrm{mg} / \mathrm{l}$. This result exceed WHO (1993) and FEPA (1999), which is $5 . \mathrm{mg} / \mathrm{l}$ this however makes the water unfit for any other uses.

Chromium $(\mathbf{C r})$ : The average range of chromium from water analysis in the study area is $7.28 \mathrm{mg} / \mathrm{l}$ this value exceed the WHO (1993) and FEPA (1999) guideline and standard limit of $0.05-1 \mathrm{mg} / \mathrm{l}$. Thus the water in the study area is not fit for domestic purposes.

Iron $(\mathbf{F e})$ : The range of iron obtained from the water analysis performed in the study area is $0.9 \mathrm{mg} / \mathrm{l}$ which exceed the WHO (1993) and FEPA (1999) guideline and standard with the value of $0.1 \mathrm{mg} / \mathrm{l}$. Presently, in Odoro Ikot and its environs the water quality of the surface water is not good because it exceed FEPA (1999) and internationally acceptable standards, hence the water in the study area is not suitable for drinking and domestic purposes. Thus, there is a need for remediation or clean up exercise need to be carried out and moreover more work need to be done in this area, a method of pumping water from the river to treatment plant then distribute to the people living in the study area. rendered it unsuitable for agricultural uses by the community.

Electrical Conductivity (EC): The electrical conductivity of the soil obtained from the study area rages from $968-986 \mu \mathrm{s} / \mathrm{cm}$. This result is highly exceeds $4 \mu \mathrm{s} / \mathrm{cm}$, which is FEPA (1999) standards for soil quality. The soil salinity is so high and most plants and sensitive crops start to be affected because the soil has been contaminated and made unfit for agriculture.

Iron :The range of iron from the soil analysis in the study area was $1.5-4.4 \mathrm{mg} / \mathrm{kg}$ which exceeds the 0.5 $1.0 \mathrm{mg} / \mathrm{kg}$ FEPA (1999) standards provided the which activated some oxidizes and is considered necessary for chlorophyll synthesis does not meet the FEPA guideline limit plant growth and crop-production will be immensely reduced due to the pollution of the soil by the oil spillage. It is unsuitable for agricultural purposes.

Copper (cu) : The range of copper from the soil analysis made in the study area was 21.60$36.90 \mathrm{mg} / \mathrm{kg}$ or $10.80-15-65 \mathrm{mg} / \mathrm{l}(\mathrm{ppm})$. This analysis exceeds the 10.1ppm FEPA (1999) standards for soil quality. The copper being in excess can cause toxicity and degradation of the soil thereby affecting the crop growth. Phosphorus (P) Phosphorus ranges from 10$45-12.35 \mathrm{mg} / \mathrm{kg}$ from the soil analysis carried out in Odoro Ikot and its environs. The result obtained for phosphorus is little bit considerable when compared

Table 1 percent of heavy metal/pollutants present on soil/

\begin{tabular}{|c|c|c|c|c|c|c|c|c|c|}
\hline SN & SAMPLE ID & $\mathrm{Pb}(\mathrm{mg} / \mathrm{kg})$ & $\mathrm{Hg}(\mathrm{Mg} / \mathrm{kg})$ & $\mathrm{Cd}(\mathrm{Mg} / \mathrm{kg})$ & $\mathrm{Cu}(\mathrm{Mg} / \mathrm{kg})$ & $\mathrm{Ni}(\mathrm{Mg} / \mathrm{kg})$ & $\mathrm{Zn}(\mathrm{Mg} / \mathrm{kg})$ & $\mathrm{Cr}(\mathrm{Mg} / \mathrm{kg})$ & $\mathbf{F e}$ \\
\hline 1. & Soil $(5 \mathrm{~cm})$ & 0 & $<0.001$ & 25.20 & 21.60 & 20.80 & 118.40 & 30.40 & 2.30 \\
\hline 2. & Soil $(10 \mathrm{~cm})$ & 120.32 & $<0.001$ & 24.82 & 31.30 & 21.20 & 100.9 & 56.80 & 4.32 \\
\hline 3. & Soil $(15 \mathrm{~cm})$ & 130.48 & $<0.001$ & 25.42 & 36.90 & 26.84 & 111.64 & 36.40 & 3.20 \\
\hline 4. & Soil $(20 \mathrm{~cm})$ & 90.04 & $<0.001$ & 25.20 & 32.90 & 25.68 & 181.64 & 39.20 & 4.40 \\
\hline 5. & Soil $(25 \mathrm{~cm})$ & 84.60 & $<0.001$ & 27.40 & 24.76 & 20.36 & 108.56 & 20.20 & 2.20 \\
\hline 6. & Soil (30cm) & 81.76 & $<0.001$ & 23.60 & 22.28 & 20.00 & 96.20 & 28.40 & 1.50 \\
\hline 7. & Water & 10.14 & $<0.001$ & 2.88 & 5.88 & 6.30 & 3.45 & 7.28 & 0.90 \\
\hline
\end{tabular}

Chemical Parameters For Soil Sample: The range of soil $\mathrm{pH}$ in Odoro Ikot and its environs is 5.21-5.60. This result does not meet the FEPA (1999) neutral (7). Because of the high $\mathrm{pH}$ of the soil, there are trace elements deficient and microbial activity which is strongly $\mathrm{pH}$ dependent reduced thereby rendering the soil useless. The oil obviously polluted the soil and to WHO and FEPA standard (11 and above) though plants, crops and microbial activity will be seriously influenced, thus the soil is unfit for agriculture.

Sulphate $\left(\mathrm{SO}^{2-}\right)$ the average range of sulphate from soil analysis the study area is $27.84-28.25 \mathrm{mg} / \mathrm{kg}$ but S04 ${ }^{-2}$ has been determined by FEPA. 
Effects of oil spillage on Soil 191

Table 2 percentage of $\mathrm{SO}_{4}$, Pox, EC,

\begin{tabular}{|l|l|l|l|l|l|l|l|l|}
\hline $\mathrm{pH}$ & $\begin{array}{l}\mathrm{Con} \mu \\
\mathrm{s} / \mathrm{cm}\end{array}$ & $\begin{array}{l}\text { Oil } \\
(\mathrm{mg} / \mathrm{l})\end{array}$ & $\begin{array}{l}\mathrm{Cu} \\
(\mathrm{mg} / \mathrm{l})\end{array}$ & $\mathrm{Pb}(\mathrm{mg} / \mathrm{l})$ & $\mathrm{Zn} \mathrm{(mg/l)}$ & $\mathrm{Cd}(\mathrm{mg} / \mathrm{l})$ & $\mathrm{Cr}(\mathrm{mg} / \mathrm{l})$ & $\mathrm{Fe}(\mathrm{mg} /)$ \\
\hline $\begin{array}{l}6.5- \\
8.5\end{array}$ & $4 \mu \mathrm{s} / \mathrm{cm}$ & 0.05 & 0.1 & 0.05 & 5.0 & 0.01 & 0.05 & 0.1 \\
\hline
\end{tabular}

oil/ grease and $\mathrm{pH}$ on soil water

Table 3 WHO standard (WHO 1993) for drinking water

\begin{tabular}{|l|c|l|l|l|l|l|l|l|}
\hline $\mathrm{pH}$ & $\begin{array}{l}\mathrm{Con} \mu \\
\mathrm{s} / \mathrm{cm}\end{array}$ & $\begin{array}{l}\text { Oil } \\
(\mathrm{mg} / \mathrm{l})\end{array}$ & $\begin{array}{l}\mathrm{Cu} \\
(\mathrm{mg} / \mathrm{l})\end{array}$ & $\begin{array}{l}\mathrm{Pb} \\
(\mathrm{mg} / \mathrm{l})\end{array}$ & $\mathrm{Zn}(\mathrm{mg} / \mathrm{l})$ & $\mathrm{Cd}(\mathrm{mg} / \mathrm{l})$ & $\mathrm{Cr}(\mathrm{mg} / \mathrm{l})$ & $\mathrm{Fe}(\mathrm{mg} /)$ \\
\hline $6.5-8.5$ & 1400 & $0.01-0.5$ & 1.5 & 0.05 & 5.0 & $0.05-1.0$ & $0.05-1.0$ & $0.1-1.0$ \\
\hline
\end{tabular}

Tahle 4 Fena Standards 1999

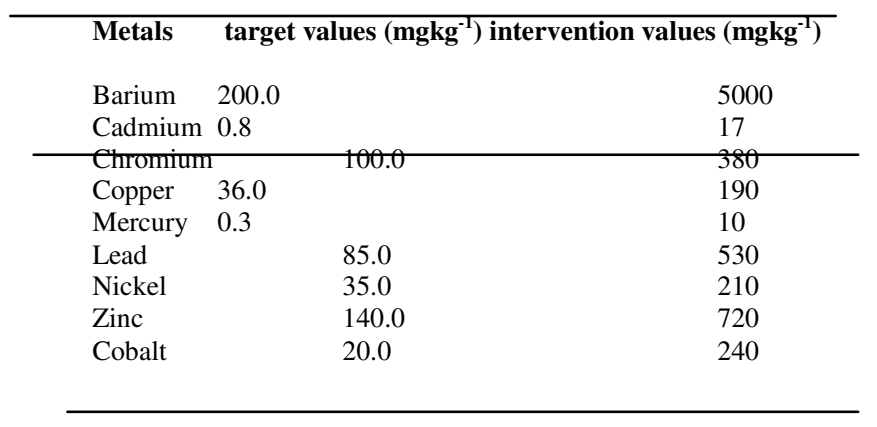

$\mathrm{Pb}$

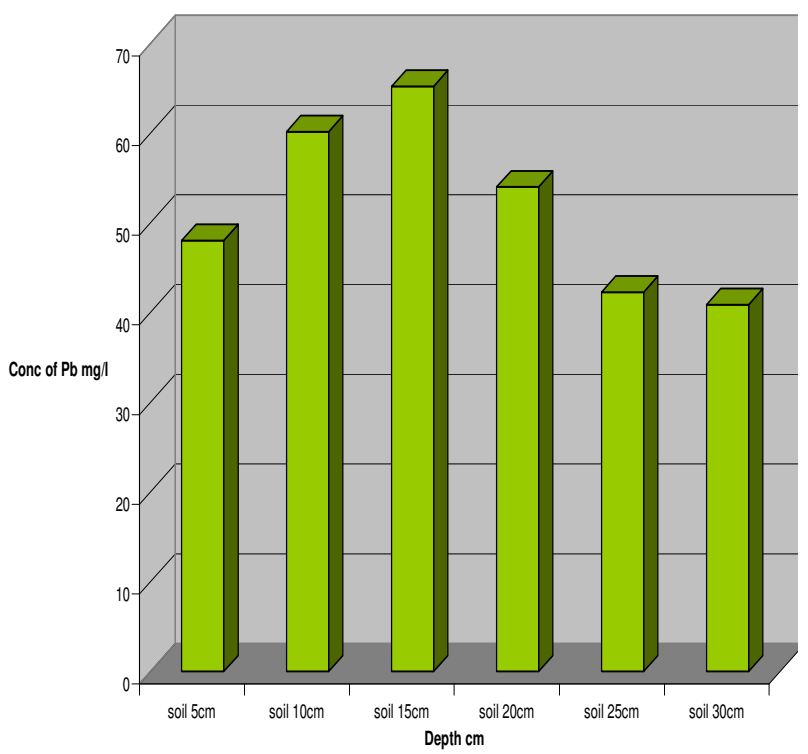

Fig.2 Histograms showing comparison between FEPA standard for soil and the sample analysis $(\mathrm{Pb})$ result
$\mathrm{Cu}$

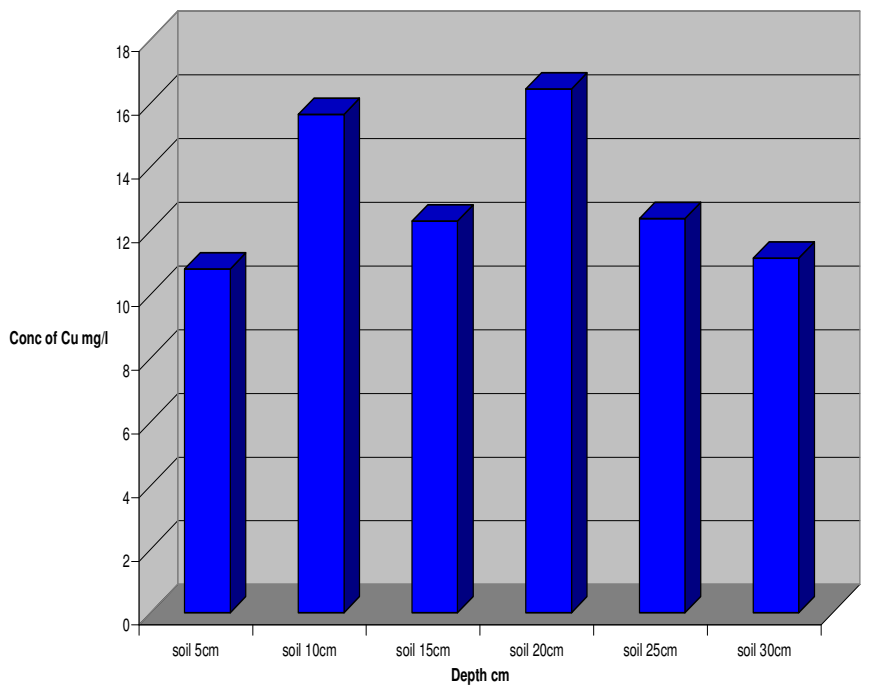

Fig.3 Histograms showing comparison between FEPA standard for soil and the sample analysis $(\mathrm{Cu})$ result 
Effects of oil spillage on Soil

$\mathrm{Ni}$

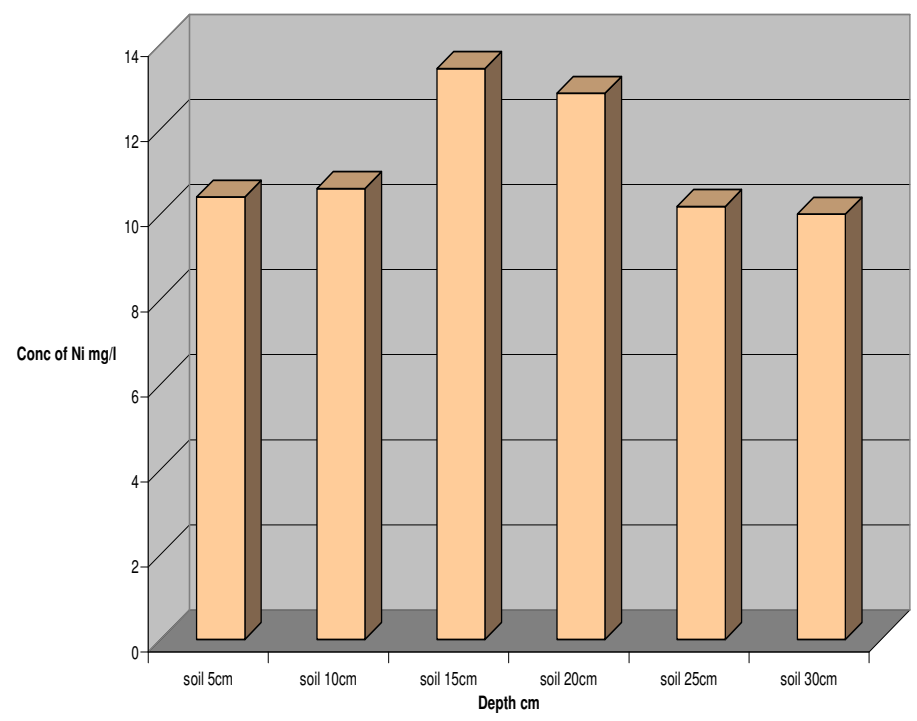

Fig.4 Histograms showing comparison between FEPA standard for soil and the sample analysis (Ni) result

$\mathrm{Cd}$

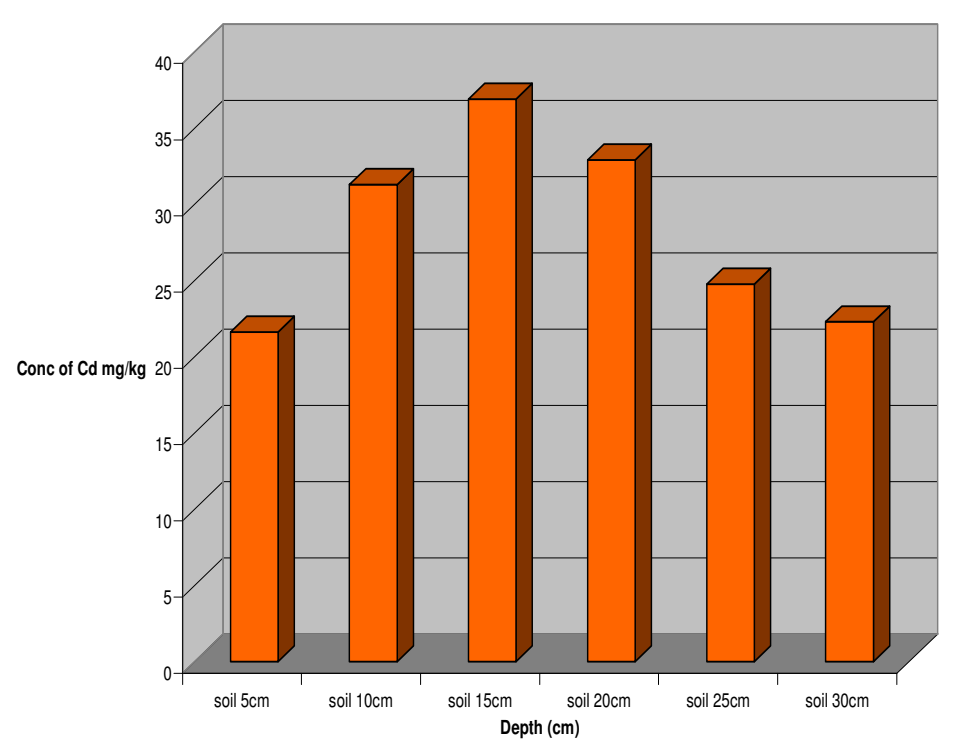

Fig:6 Histograms showing comparison between DPR standard for soil and the sample analysis $(\mathrm{Cd})$ result
$\mathrm{Pb}$

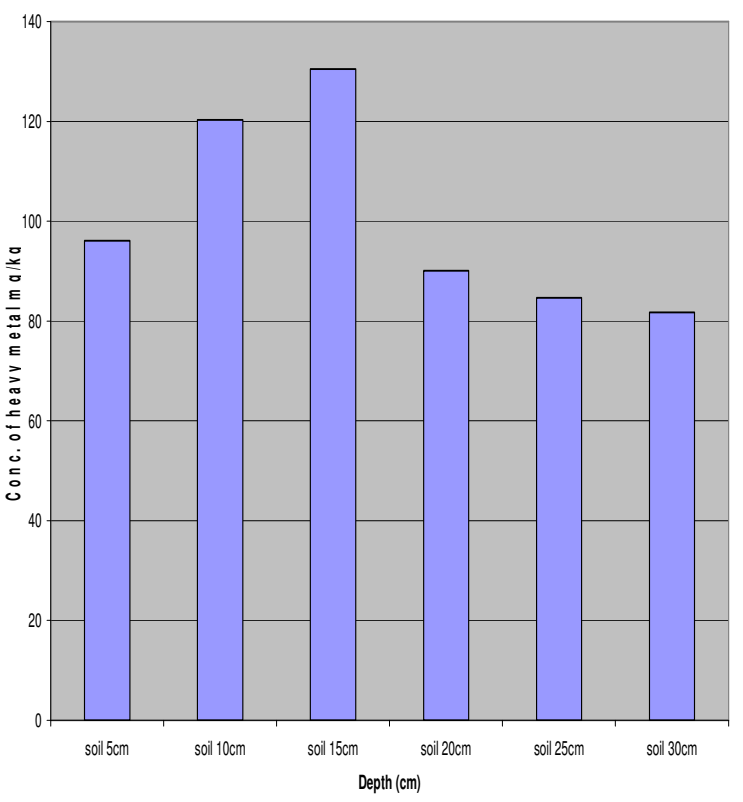

Fig.5 Histograms showing comparison between DPR standard for soil and the sample analysis $(\mathrm{Pb})$ result

$\mathrm{Cu}$

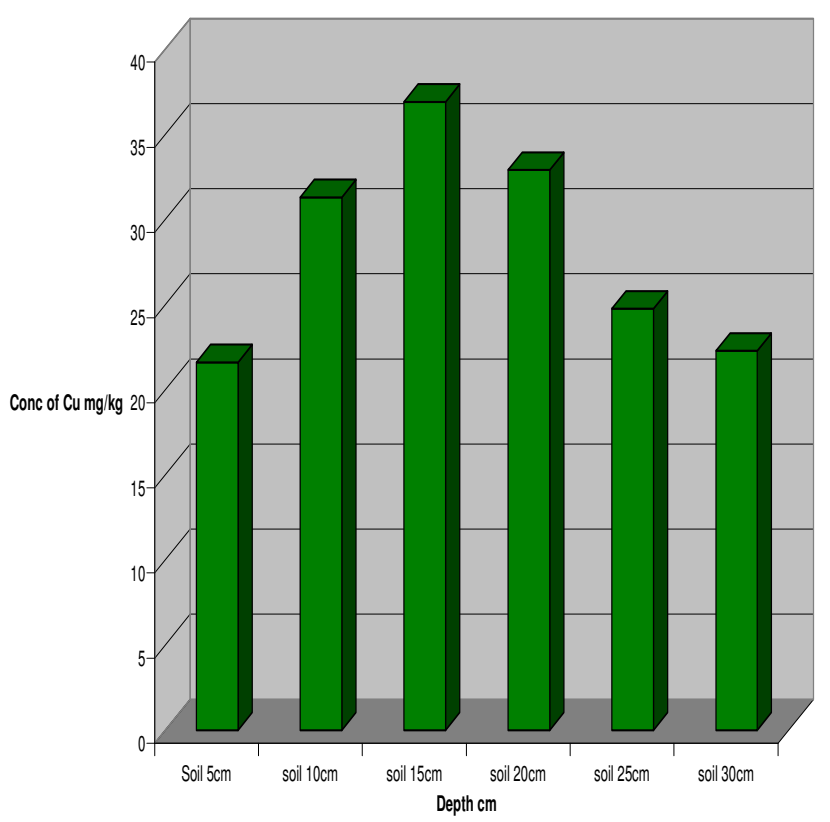

Fig:7 Histograms showing comparison between DPR standard for soil and the sample analysis $(\mathrm{Cu})$ result 
Conclusion: This work emphasizes on the assessment of the effect of oil spillage on surface water and soil in the study area using AAS. Laboratory technique, guideline limit and standards. From the comparative assessment of the analytical results with WHO (1993), DPR (2002) and FEPA (1999) standards, the surface water sample exceed the FEPA and internationally acceptable $\mathrm{pH}$ was almost acidic and oil/grease value in the location was above the internationally acceptable standards, hence the water are not portable or not suitable for drinking and domestic purposes.

The soil sample analytical results show that the oil has immensely polluted the soil and made unfit for agricultural activities, and requires remediation.

To keep the environment safe, the causes of oil spillage should be properly checked while the environment has to be monitored through regular studies in oil producing areas.

\section{REFERENCES}

Akpokodje, E. G. 2001. Introduction to engineering Geology, Pam Unique Publishing Coy Ltd, Box 74, Uniport Post Office; Choba, Port Harcourt.

Department of Petroleum Resources DPR (2002). Standard for soil Pg 213-219
Gesamp,1990:/MCO/FAO/UNESCO/WHO/LEAEA /UN/UNEP: Joint Group of Experts on Scientific Aspects of Marine Pollution. The States of the Marine Environment. UNEP Regional Sea eport and Studies No. 115 pp.45

Egboka, B. C. E. 1988 The Hydrogeological provinces of Nigeria WREPU, Department of Geological Sciences, Anambra State University of Technology Enugu, Nigeria. pp: 117-125

Federal Environmental Protection Agency (FEPA), 1999. National Guidelines and Standards for Soil Quality in Nigeria. FEPA, Rivers State Ministry of Environment and Natural Resources, Port Harcourt.

Federal Environmental Protection Agency (FEPA), 1999. National Guidelines and Standards for Water Quality in Nigeria. FEPA, Akwa Ibom State Ministry of Environment and Natural Resources, Uyo.

Frank, E. J and Cordry, E. A. 1967. The Niger Delta Oil Provine, Recent World Petroleum Congress, Proc, Vol. 2 -Pp-195-209.

World Health Organization WHO (1993) Standard for drinking water. $\mathrm{Pg}$ 92-93. 